\section{REFERENCES}

1. Krumholz HM, Sande MA, Lo B. Community-acquired bacteremia in patients with acquired immunodeficiency syndrome: clinical presentation, bacteriology and outcome. Am J Med 1989;86:776-779.

2. Raviglione MC, Battan R, Pablos-Mendez A, Aceves-Casillas P, Mullen MP, Taranta A. Infections associated with Hickman catheters in patients with the acquired immunodeficiency syndrome. Am J Med 1989;86:780-786.

3. Skoutelis AT, Murphy RL, MacDonell KB, VonRoenn JH, Sterkel CD, Phair JP. Indwelling central venous catheter infections in patients with acquired immune deficiency syndrome. J Acquir Immune Defic Syndr Hum Retroviral 1990;3:335-342.

4. Stroud L, Srivastava P, Culver D, Bisno A, Rimland D, Simberkoff M, et al. Nosocomial infections in HIV-infected patients: preliminary results from a multicenter surveillance system (1989-1995). Infect Control Hosp Epidemiol 1997;18:479-485.

5. Knapp CC, Ludwig MD, Washington JA. Evaluation of differential inoculum disk diffusion method and Vitek GPS-SA card for detection of oxacillin-resistant staphylococci. J Clin Microbiol 1994;32:433-436.

6. Garner JS, Jarvis WR, Emori TG, Horan TC, Hughes JM. CDC definitions for nosocomial infections, 1988. Am J Infect Control 1988;16:128-140.

7. Crossley K, Loesch D, Landesman B, Mead K, Chern M, Strate R. An outbreak of infections caused by strains of Staphylococcus aureus resistant to methicillin and aminoglycosides, I: clinical studies. I Infect Dis 1979;139:273-279.

8. Peacock JE Jr, Marsik FJ, Wenzel RP. Methicillin-resistant Staphylococcus aureus: introduction and spread within a hospital. Ann Intern Med 1980;93:526-532.

9. Ward TT, Winn RE, Hartstein AI, Sewell DL. Observations relating to an inter-hospital outbreak of methicillin-resistant Staphylococcus aureus: role of antimicrobial therapy in infection control. Infect Control 1981;2:453-459.

10. Locksley RM, Cohen ML, Quinn TC, Tompkins LS, Coyle MB, Kirihara JM, et al. Multiply antibiotic-resistant Staphylococcus aureus: introduction, transmission, and evolution of nosocomial infection. Ann Intern
Med 1982:97:317-324.

11. Bitar CM, Mayhall CG, Lamb VA, Bradshaw TJ, Spadora AC, Dalton HP. Outbreak due to methicillin- and rifampin-resistant Staphylococcus aureus: epidemiology and eradication of the resistant strain from the hospital. Infect Control 1987;8:15-23.

12. Rimland D. Nosocomial infections with methicillin and tobramycin resistant Staphylococcus aureus-implication of physiotherapy in hospitalwide dissemination. Am J Med Sci 1985;290:91-97.

13. Arnow PM, Allyn PA, Nichols EM, Hill DL, Pezzlo M, Bartlett RH. Control of methicillin-resistant Staphylococcus aureus in a burn unit: role of nurse staffing. J Trauma 1982;22:954-959.

14. Lentino JR, Hennein H, Krause S, Pappas S, Fuller G, Schaaf D, et al. A comparison of pneumonia caused by gentamicin, methicillin-resistant and gentamicin, methicillin-sensitive Staphylococcus aureus: epidemiologic and clinical studies. Infect Control 1985;6:267-272.

15. Pujol M, Peña C, Pallares R, Ayats J, Ariza J, Gudiol F. Risk factors for nosocomial bacteremia due to methicillin-resistant Staphylococcus aureus. Eur J Clin Microbiol Infect Dis 1994;13:96-102.

16. Boyce JM, Landry M, Deetz TR, DuPont HL. Epidemiologic studies of an outbreak of nosocomial methicillin-resistant Staphylococcus aureus infections. Infect Control 1981;2:110-116.

17. Leyden JJ, Marples RR, Kligman AM. Staphylococcus aureus in the lesions of atopic dermatitis. Br J Dermatol 1974;90:525-530.

18. Bibel DJ, Greenberg JH, Cook JL. Staphylococcus aureus and the microbial ecology of atopic dermatitis. Can J Microbiol 1977;23:1062-1068.

19. Hanifin JM, Rogge JL. Staphylococcal infections in patients with atopic dermatitis. Arch Dermatol 1977;113:1383-1386.

20. Dahl MV. Staphylococcus aureus and atopic dermatitis. Arch Dermatol 1983;119:840-846.

21. Aly R, Maibach HI, Mandel A. Bacterial flora in psoriasis. Br J Dermatol 1976;95:603-606.

22. Marples RR, Heaton CL, Kligman AM. Staphylococcus aureus in psoriasis. Arch Dermatol 1973;107:568-570.

23. Noble WC, Savin JA. Carriage of Staphylococcus aureus in psoriasis. BMJ 1968;1:417-418.

\title{
Professor Alexi Petrovich Krasilnikow
}

The Rectorate of the Minsk State Medical Institute and the Directors of the Belarussian Research Institute for Epidemiology and Microbiology with great sadness report the death of Alexi Petrovich Krasilnikow, Professor of the Department of Microbiology, Virology, and Immunology at the Minsk State Medical Institute, Vice President of the Belarus Scientific Society of Epidemiologists and Microbiologists and the Belarus Scientific Society of Immunologists and Allergists, and member of the editorial boards of Infection Control and Hospital Epidemiology (1982-1997) and the Journal of Microbiology (Moscow).

Professor Krasilnikow was born on February 19, 1918. After military service from 1939 to 1947 , he entered the Minsk State Medical Institute, where he rose to become head of the Department of Microbiology, Virology, and Immunology. Professor Krasilnikow's scientific interests in topics such as leptospirosis, dysentery, sclerema, ozena, epidemiology, hospital infections, and resistance of bacteria to antibiotics and disinfectants sparked 14 monographs and more than 380 scientific works. Professor
Krasilnikow was a talented teacher and participated constantly in the training of medical, scientific, and educational specialists. He received the Order of the Red Star, two Orders of the Patriotic War, nine medals, and was honored by the Belarus Supreme Council. His memory will live on in the hearts of his friends, collaborators, and students.

Professor Leonid P. Titov

Head, Department of Microbiology, Virology, and Immunology Minsk State Medical Institute Minsk, Republic of Belarus 